\title{
Analisis Sentimen Publik dari Twitter Tentang Kebijakan Penanganan Covid-19 di Indonesia dengan Naive Bayes Classification
}

\author{
Ni Putu Gita Naraswati*, Delvira Cindy Rosmilda, Dinda Desinta, \\ Fadhilatul Khairi, Riska Damaiyanti, Rani Nooraeni \\ Prodi D-IV Statistika, Politeknik Statistika STIS, \\ Jl. Otto Iskandardinata No.64C, Jatinegara, Jakarta Timur \\ *e-mail:211709894@stis.ac.id
}

(received: 20 Desember 2020, revised: 27 Desember 2020, accepted: 9 Januari 2021)

\begin{abstract}
Abstrak
Beberapa bulan terakhir, penanganan COVID-19 menjadi salah satu permasalahan kompleks yang dihadapi oleh hampir seluruh negara di dunia. Menilik dari hal tersebut, pemerintah membentuk kebijakan guna mencegah semakin meluasnya penyebaran virus diantaranya Pembatasan Sosial Berskala Besar (PSBB), wajib masker, dan jam malam. Kebijakan tersebut mendapat tanggapan yang beragam, tidak terkecuali di media sosial seperti twitter. Berdaarkan hal tersebut, penelitian ini bertujuan untuk menganalisis sentimen publik dari cuitan Twitter mengenai penanganan COVID-19 di Indonesia. Adapun metode yang digunakan Nä̈ve Bayes Classification karena memiliki algoritma yang sederhana dengan akurasi yang tinggi. Hasil penelitian menunjukkan, masyarakat lebih banyak memberikan sentimen negatif terhadap kebijakan penanganan COVID-19 khususnya PSBB, wajib masker, dan jam malam. Pada sentimen positif, tiga kata dengan frekuensi kemunculan terbanyak yaitu demo, jakarta, dan kerja. Sedangkan pada sentimen negatif yaitu jakarta, demo, dan orang. Kemunculan kata "demo" dan "jakarta" pada kedua sentimen menunjukkan bahwa tweet masyarakat mengenai kebijakan penanganan COVID-19 tidak lepas dari peristiwa/kejadian saat pengumpulan data dilakukan. Selain itu, tingginya frekuensi kata "jakarta" pada sentimen negatif juga menunjukkan bahwa pelaksanaan kebijakan penanganan COVID-19 di Jakarta belum dilaksanakan secara optimal. Berdasarkan hasil evaluasi, diperoleh tingkat akurasi klasifikasi sebesar 87,34\%, sensitivitas sebesar 93,43\%, dan spesifisitas 71,76\% yang berarti metode ini sudah cukup baik.
\end{abstract}

Kata Kunci: COVID-19, naïve bayes classification, kebijakan, text mining, twitter

\begin{abstract}
In recent months, handling COVID-19 has become one of the complex problems faced by almost all countries in the world. In view of this, the government formed policies to prevent the spread of the virus, including Large-Scale Social Restrictions (PSBB), mandatory masks, and curfews. This policy received various responses, including on social media such as Twitter. Based on this, this study aims to analyze public sentiment from Twitter tweets regarding the handling of COVID-19 in Indonesia. The method used is the Naïve Bayes Classification because it has a simple algorithm with high accuracy. The results showed that the public gave more negative sentiments towards the policy of handling COVID-19, especially PSBB, mandatory masks, and curfews. On the positive sentiment, the three words with the highest frequency were "demo", "jakarta", and "work". Meanwhile, the negative sentiment is "jakarta", "demo", and "orang". The appearance of the words "demo" and "jakarta" in both sentiments shows that the public's tweet regarding the policy for handling COVID19 cannot be separated from the events / incidents when data collection was carried out. In addition, the high frequency of the word "jakarta" in negative sentiments also shows that the implementation of policies for handling COVID-19 in Jakarta has not been implemented optimally. Based on the evaluation results, the classification accuracy rate is $87.34 \%$, the sensitivity is $93.43 \%$, and the specificity is $71.76 \%$, which means that this method is good enough.
\end{abstract}

Keywords: COVID-19, naïve bayes classification, policy, text mining, twitter 


\section{Pendahuluan}

Beberapa bulan terakhir, penanganan COVID-19 menjadi salah satu permasalahan kompleks yang dihadapi oleh hampir seluruh negara di dunia. COVID-19 merupakan penyakit yang bermula di daerah Wuhan, Tiongkok pada Bulan November 2019, disebabkan oleh coronavirus jenis baru dengan tingkat penularan tinggi. Sejak kejadian luar biasa muncul di Wuhan Cina, pada Desember 2019, World Health Organization (WHO) kemudian memberi nama coronavirus jenis baru yang ditemukan pada manusia tersebut sebagai Severe Acute Respiratory Syndrome Coronavirus 2 (SARSCOV2) yang menjadi penyebab dari Coronavirus Disease-2019 (COVID-19) [1]. Pada tanggal 16 Maret 2020, keberadaan COVID-19 kemudian ditetapkan menjadi pandemi karena penyebarannya yang telah mencapai sebagian besar negara di dunia. Berangkat dari penetapan tersebut, setiap negara diharapkan dapat mengaktifkan dan meningkatkan mekanisme tanggap darurat untuk meminimalisasi korban dan mengupayakan pencegahan terhadap penyebarannya yang meluas.

Di Indonesia, penyebaran virus ini juga telah meluas dimana hingga tanggal 11 September 2020, tercatat 210.940 orang terkonfirmasi positif dan sebanyak 8.544 orang meninggal akibat COVID-19 [2]. Pemerintah kemudian menanggapi dengan penanganan yang dilakukan melalui berbagai kebijakan, termasuk pada bidang kesehatan. Salah satunya adalah memastikan dilaksanakannya protokol kesehatan oleh seluruh masyarakat guna mencegah semakin meluasnya penyebaran virus dan meningkatnya jumlah korban. Kebijakan yang digalakkan pemerintah diantaranya Pembatasan Sosial Berskala Besar (PSBB), aturan wajib masker, dan penerapan jam malam. Kebijakan-kebijakan tersebut diharapkan dapat memastikan masyarakat tetap melaksanakan protokol kesehatan pada masa adaptasi kebiasaan baru atau new normal.

Namun, kebijakan-kebijakan tersebut tidak seluruhnya dilaksanakan oleh masyarakat sehingga masih ditemukan pelanggaran atas kebijakan yang berlaku. Keadaan juga diperparah dengan keberadaan beberapa pihak yang meragukan efektivitas kebijakan yang ada. Hal tersebut diperparah dengan adanya fenomena matinya kepakaran (the death of expertise) yang berkembang di masyarakat. Tom Nichols dalam bukunya Matinya Kepakaran menyatakan bahwa fenomena ini dapat dilihat dari sikap masyarakat yang cenderung tidak percaya terhadap pernyataan pakar yang tercermin dari sikap bebal dalam mengikuti kebijakan pemerintah yang ada [3]. Di sisi lain, pelaksanaan kebijakankebijakan ini dari sisi pemerintah juga perlu diperhatikan mengingat pelaksanaan prosedur yang tidak sesuai juga dapat memicu kekurangpercayaan masyarakat dalam melaksanakan kebijakan yang ada.

Berangkat dari hal tersebut, masyarakat seringkali memberikan komentar melalui berbagai media sosial, tidak terkecuali pada Twitter. Twitter merupakan salah satu media dalam berjejaring sosial dimana penggunanya dapat mengirim hingga 140 karakter yang disebut tweet atau kicauan [4]. Di sisi lain terdapat teks mining yang memungkinkan adanya pengolahan informasi lama secara eksplisit di dalam komputer sehingga mendukung temuan informasi baru dari media sosial termasuk twitter [5]. Menilik dari hal tersebut, cuitan komentar masyarakat terhadap kebijakan yang berlaku merupakan hal yang penting untuk dianalisis agar pemerintah dapat mengetahui respon masyarakat terhadap kebijakan penanganan COVID-19 ini. Komentar yang diberikan dapat berupa apapun, baik secara positif maupun negatif sehingga salah satu cara yang dapat digunakan adalah analisis sentimen. Analisis sentimen merupakan salah satu domain penting dalam machine learning [6]. Studi yang melakukan analisis pendapat, evaluasi, sentimen, sikap, penilaian, dan emosi terhadap entitas seperti layanan, individu, masalah, topik, dan atributnya juga didasari oleh analisis sentimen [7]. Hasil tersebut dapat dijadikan sebagai evaluasi dan acuan dalam penyusunan kebijakan selanjutnya. Selanjutnya, dapat dilakukan peninjauan kembali kebijakan yang ada ataupun mengatasi masalah dalam masyarakat sebagai penerima informasi dan pihak yang melaksanakan kebijakan. Oleh karena itu, pada penelitian ini dilakukan analisis sentimen dengan metode klasifikasi Naive Bayes Classification. Metode Naïve Bayes dipilih karena metode ini memiliki algoritma yang sederhana dengan akurasi yang tinggi [8]. Tujuan penelitian ini adalah menganalisis sentimen publik dari cuitan Twitter mengenai penanganan COVID-19 di Indonesia. Penelitian ini diharapkan memberikan manfaat yaitu menambah pengetahuan mengenai analisis sentimen publik dari twitter sehingga dapat menjadi referensi pada penelitian selanjutnya yang berhubungan dengan topik terkait. Adapun keterbaruan penelitian ini dari penelitian sebelumnya adalah penggunaan keyword yang mengacu pada 
nama kebijakan pemerintah terkait penanganan COVID-19 serta dilihat dari segi waktu pengumpulan tweet yang lebih terkini.

\section{Tinjauan Literatur}

Analisis sentimen publik telah banyak digunakan dalam berbagai penelitian. Salah satunya adalah penelitian yang dilakukan oleh Sisferi Hikmawan, dkk. pada tahun 2019 yang membahas tentang Analisis Sentimen Publik Terhadap Joko Widodo Terhadap Wabah COVID-19 Menggunakan Metode Machine Learning [9] yang mengklasifikasikan sentimen publik berdasarkan cuitan di twitter. Penelitian tersebut menganalisis sentimen publik mengenai suatu kebijakan pemerintah dengan proses analisa data mining yang termasuk metode yang sering digunakan. Dalam penelitian ini digunakan kata kunci "Jokowi" dan "Covid". Penelitian ini menganalisis dan membandingkan tiga metode klasifikasi yaitu Naive Bayes, Support Vector Machine, dan k-NN. Hasil penelitian menunjukkan bahwa nilai terbaik ditunjukkan oleh metode Support Vector Machine (SVM) dengan accuracy $92,93 \%$, precision $95,70 \%$ dan recall 89,17\%. Selanjutnya, Naive Bayes berada di posisi kedua dengan accuracy $84,58 \%$, precision $82,14 \%$ dan recall $85,82 \%$. Terdapat tiga kelas sentimen yang di klasifikasikan, yaitu: sentimen positif, negatif dan netral.

Penelitian lain mengenai analisis sentimen juga dilakukan oleh Bimananda W, dkk, pada tahun 2019 [10]. Penelitian ini mengangkat tema Analisis Text Mining dari Cuitan Twitter Mengenai Infrastruktur Indonesia dengan Metode Naïve Bayes. Berdasarkan hasil pengklasifikasian dengan menggunakan Naive Bayes diperoleh hasil akurasi, presisi, dan recall yang cukup baik untuk semua variabel yang digunakan untuk menggambarkan pembangunan infrastruktur, terutama pada variabel bandara karena memiliki akurasi yang tertinggi, presisi, dan recall yang cukup baik. Penelitian ini hanya menggunakan tweet berbahasa Indonesia.

Muhammad Syarifuddin juga melakukan penelitian mengenai analisis sentimen opini publik yang dilakukan pada tahun 2020 [5]. Penelitian tersebut membahas tentang Analisis Sentimen Opini Publik Mengenai COVID-19 pada Twitter Menggunakan Metode Nä̈ve Bayes dan KNN. Berdasarkan hasil pengujian menggunakan metode Nä̈ve Bayes dan KNN, menunjukkan bahwa opini masyarakat cenderung positif. Dari kedua metode yang digunakan, hasil klasifikasi dengan metode Nä̈ve Bayes lebih unggul dibandingkan dengan metode KNN ditinjau dari nilai accuracy, precision, recal, F-Measure, dan AUC (Area Under Curve). Hasil klasifikasi dengan menggunakan Nä̈ve Bayes diperoleh nilai accuracy sebesar $63,21 \%$, precision sebesar $59,11 \%$, recall sebesar $56,80 \%, F$ Measure sebesar 57,96\%, dan AUC sebesar 0,862. Sehingga model klasifikasi Nä̈ve Bayes lebih baik dan lebih akurat untuk mengklasifikasikan data yang ada dibandingan dengan model klasifikasi KNN.

\section{Metode Penelitian}

\subsection{Data}

Data yang digunakan pada penelitian ini bersumber dari data Twitter yang berupa tweet berbahasa Indonesia yang di-post di seluruh wilayah Indonesia. Twitter sendiri merupakan salah satu situs microblogging yang memungkinkan penggunanya untuk menulis mengenai berbagai topik dan membahas isu-isu yang terjadi saat ini [10]. Jejaring sosial twitter juga seringkali digunakan sebagai tempat menyampaikan tanggapan atau pendapat mengenai sesuatu hal berupa cuitan atau tweet yang dapat berupa tanggapan secara positif maupun negatif. Kata kunci yang digunakan yaitu PSBB, wajib masker, dan jam malam. Data diambil dari twitter dengan metode crawling menggunakan software $\mathrm{R}$ Studio dengan terlebih dahulu harus mempunyai akun twitter.

\subsection{Ruang Lingkup Penelitian}

Penelitian ini mengangkat masalah respon pengguna twitter terkait beberapa kebijakan pemerintah dalam penanganan COVID-19 yaitu PSBB, wajib masker, dan jam malam. Adapun jumlah cuitan/tweet yang dianalisis dalam penelitian ini adalah 10.000 cuitan pada 5-7 Oktober 2020. Rentang waktu ini dipilih karena merupakan masa yang mendekati berakhirnya salah satu kebijakan terkait penanganan COVID-19 yaitu PSBB Masa Transisi Menuju Masyarakat Sehat, Aman, dan Produktif di DKI Jakarta. Cuitan/tweet tersebut nantinya akan dijadikan objek untuk melakukan analisis sentimen. 


\subsection{Teknik Analisis}

Pada penelitian ini, dilakukan analisis klasifikasi (supervised learning) yang merupakan suatu teknik statistik yang bertujuan untuk mengelompokkan data ke dalam kelas-kelas yang telah memiliki label dengan membangun suatu model yang berdasarkan kepada suatu data training serta memprediksi kelas dari suatu data baru [11]. Sedangkan, data training adalah satu set data yang telah diketahui klasifikasinya. Pengertian lainnya yaitu supervised learning (analisis klasifikasi) adalah suatu metode klasifikasi di mana kumpulan data sepenuhnya diberikan label untuk selanjutnya diklasifikasikan ke dalam kelas yang tidak dikenal [12]. Muhammad dan Yan [13] menyatakan bahwa tujuan utama dari supervised learning adalah mempelajari fungsi target yang dapat digunakan untuk memprediksi nilai dari suatu kelas.

Pada metode Nä̈ve Bayes Classifier diasumsikan bahwa fitur (kata) memiliki nilai yang independen pada posisi kata. Berikut ini adalah tahapan penggunaan metode Naive Bayes dalam penelitian ini:

\section{Pre-Processing Data}

Data yang dikumpulkan merupakan data yang tidak terstruktur sehingga diperlukan PreProcessing. Berikut ini adalah yang dilakukan pada tahap Pre-Processing:

\section{a. Tokenization}

Tokenisasi adalah proses yang dilakukan untuk memecah konten tekstual menjadi kata-kata, istilah, simbol, atau beberapa elemen bermakna lainnya. Hasil pemecahan ini kemudian disebut dengan token.

b. Cleansing

Cleansing merupakan proses yang dilakukan untuk membuang karakter dan tanda baca yang tidak diperlukan seperti titik, koma, tanda seru, tanda tanya, termasuk menghilangkan URL dan HTML, menghapus emoji, mention atau hashtag, menghapus kata-kata slang, dan menghilangkan symbol atau huruf yang tidak relevan.

c. Case Folding

Case Folding adalah proses mengubah setiap huruf di tweet menjadi lowcase atau semuanya dijadikan huruf kecil.

d. Filtering

Filtering memiliki tujuan untuk menghilangkan stop words atau kata-kata yang tidak memiliki makna. Penghapusan stop words perlu dilakukan agar peneliti dapat fokus pada kata-kata lain yang lebih penting.

e. Stemming

Stemming merupakan proses yang bertujuan mengubah kata yang berimbuhan menjadi kata dasar.

2. Pelabelan Data

Proses ini bertujuan membagi data menjadi tiga kelas sentimen, yaitu sentimen positif, sentimen negatif, dan sentimen netral, namun dalam penelitian ini yang digunakan hanyalah sentimen positif dan negatif. Cara tersebut sejalan dengan penelitian analisis sentimen yang dilakukan oleh Hikmawan, Pardamean, dan Khasanah [9]. Pembagian label didasarkan pada kamus sentimen yang bersumber dari penelitian yang berjudul Analisis Sentimen Masyarakat terhadap Calon Presiden Indonesia 2019 Berdasarkan Opini dari Twitter Menggunakan Metode Naive Bayes Classifier [14]. Pada proses ini, data dibagi menjadi dua bagian, yaitu data training dan data testing. Data yang digunakan untuk melatih sistem agar dapat mengenali pola yang dicari disebut sebagai data training, sedangkan data yang digunakan untuk mengevaluasi pengklasifikasian disebut data testing.

\section{Proses Klasifikasi}

Pada penelitian ini, metode klasifikasi yang digunakan adalah Nä̈ve Bayes yang merupakan sebuah metode pengelompokkan untuk memprediksi probabilitas suatu class. Naïve Bayes merupakan metode pengklasifikasian dengan metode probabilitas dan statistik yang dikemukakan oleh seorang ilmuwan inggris bernama Thomas Bayes [15]. Naïve Bayes mengasumsikan variabel prediktornya adalah independen. Maksudnya, keberadaan fitur tertentu di kelas tidak terkait dengan keberadaan fitur lainnya [16]. Misalnya, jika terdapat tiga fitur yang mendeskripsikan suatu objek, maka ketiga 
fitur tersebut secara independen memberikan kontribusi terhadap probabilias yang mendeskripsikan objek tersebut, yang disebut "Naïve". Adapun Teorema Bayes adalah sebagai berikut:

$\mathrm{P}(\mathrm{H} \mid \mathrm{X})=\frac{P(H) \cdot P(H)}{P(X)}$

Dimana:

$X \quad$ : Data dengan kelas yang belum diketahui

$H \quad$ : Hipotesis data merupakan suatu kelas spesifik

$P(H \mid X)$ : Probabilitas hipotesis $\mathrm{H}$ berdasar kondisi $\mathrm{X}$ (probabilitas posterior)

$P(H) \quad$ : Probabilitas hipotesis $\mathrm{H}$ (probabilitas prior)

$P(X \mid H)$ : Probabilitas $\mathrm{X}$ berdasarkan kondisi pada hipotesis $\mathrm{H}$

$P(X) \quad$ : Probabilitas

Selanjutnya, dilakukan evaluasi model yang meliputi akurasi, presisi, dan sensitivitas pada data testing yang bertujuan untuk mengukur ketepatan pengklasifikasian. Akurasi merupakan ukuran ketepatan pengklasifikasian yang menunjukkan performansi teknik klasifikasi secara keseluruhan, dimana semakin tinggi akurasi klasifikasi berarti semakin baik performansi teknik klasifikasi. Adapun tabel confusion matrix sebagai dasar perhitungan evaluasi model dapat dilihat pada Tabel 1.

Tabel 1. Confusion Matrix untuk Hasil Klasifikasi Biner

\begin{tabular}{ccc}
\hline Kelas & \multicolumn{2}{c}{ Kelas prediksi } \\
\cline { 2 - 3 } Sebenarnya & Positif & Negatif \\
\hline Positif & $\mathrm{tp}$ & $\mathrm{fn}$ \\
\hline Negatif & $\mathrm{fp}$ & $\mathrm{tn}$ \\
\hline
\end{tabular}

$$
\operatorname{Akurasi} \text { klasifikasi }(\%)=\frac{t p+t n}{t p+f p+t n+f n}
$$

Sensitifity $(\%)=\frac{t p}{t p+f n}$

Specificity $(\%)=\frac{t n}{f p+t n}$

4. Visualisasi

Visualiasasi pada penelitian ini menggunakan wordcloud. Wordcloud menampilkan kata-kata yang menjelaskan setiap kelompok klasifikasi.

\section{Hasil dan Pembahasan}

\subsection{Preprocessing Data}

Data yang digunakan pada penelitian ini bersumber dari Twitter yang diambil dengan metode crawling. Adapun variabel yang dijadikan sebagai variabel untuk menggambarkan dampak (sentimen) publik terhadap wabah COVID-19 di Indonesia menggunakan kata kunci antara lain "jam malam", "PSBB", dan "wajib masker". Data ini kemudian dilakukan preprocessing yang mencakup tokenizing, cleansing, case folding, filtering, dan stemming, agar diperoleh data yang siap digunakan pada tahap analisis sentimen. Setelah melewati tahap preprocessing, diperoleh sebesar 42,92\% (4292 tweets) data yang siap digunakan pada tahap analisis sentimen, sedangkan $57,08 \%$ sisanya merupakan tweets yang mengalami duplikasi sehingga dihapus untuk menghindari bias pada penelitian.

\subsection{Pelabelan Kelas Sentimen}

Tahapan selanjutnya setelah dilakukan preprocessing data adalah pelabelan tweet menjadi kelas sentimen positif, negatif, dan netral, namun sentimen netral tidak digunakan pada penelitian ini. Pembobotan kata dilakukan dengan menghitung frekuensi kemunculan kata. Berdasarkan 
pengelompokan kata yang digunakan dalam penelitian [14], skor sentimen dari tweet/teks komentar dihitung dengan menjumlahkan skor jumlah kata positif dikurangi dengan skor jumlah kata negatif dalam setiap kalimat [17] atau dapat ditulis sebagai berikut:

$$
\text { Skor }=\left(\sum \text { kata positif }\right)-\left(\sum \text { kata negatif }\right)
$$

Berdasarkan perhitungan tersebut, yang akan masuk ke dalam kelas negatif adalah kalimat yang memiliki skor < 0 , yang akan masuk kelas netral adalah kalimat dengan skor $=0$, sedangkan kelas positif akan terdiri dari kalimat yang memiliki skor $>0$. Namun, dalam penelitian ini hanya menggunakan dua kelas pelabelan yaitu sentimen positif dan sentimen negatif.

Tabel 2. Contoh Hasil Pelabelan Kelas Sentimen

\begin{tabular}{lcc}
\hline \multicolumn{1}{c}{ Tweets } & Skor & $\begin{array}{c}\text { Kelas } \\
\text { Sentimen }\end{array}$ \\
\hline $\begin{array}{l}\text { mohon bantu orang dagang sate dampak } \\
\text { psbb jakarta nenek sakit diabetes bantu }\end{array}$ & -2 & Negatif \\
\hline $\begin{array}{l}\text { buruh ancam mogok kerja poyuono } \\
\text { otomatis garagara psbb ala anies } \\
\text { baswedan orang gila sala }\end{array}$ & -2 & Negatif \\
\hline $\begin{array}{l}\text { psbb rawan banget ngajakin ngeroom } \\
\text { embelembel dine hilih }\end{array}$ & 1 & Positif \\
\hline $\begin{array}{l}\text { salah mahasiswa demo langgar psbb } \\
\text { kayak pemicunya yuk bapak }\end{array}$ & -1 & Negatif \\
\hline $\begin{array}{l}\text { kesah uu cipta karya langkah pemerintah } \\
\text { kontra produktif sahkan buruk pandemi }\end{array}$ & -1 & Negatif \\
\hline psbb sah cepat cepat nyata & 3 & Positif \\
\hline
\end{tabular}

Berdasarkan Tabel 2 dapat dilihat pelabelan kelas sentimen berdasarkan kata positif dan negatif yang terkandung dalam tweet. Pada teks komentar "mohon bantu orang dagang sate dampak psbb jakarta nenek sakit diabetes bantu" terdapat 2 kata negatif yang terdeteksi yaitu "nenek" dan "sakit" sedangkan tidak terdapat kata positif sehingga skor sentimennya bernilai -2. Adapun hasil sentimen pada setiap variabel adalah sebagai berikut:

Tabel 3. Hasil Pelabelan Sentimen

\begin{tabular}{cc}
\hline Pelabelan Sentimen & Banyaknya Tweet \\
\hline Sentimen Positif & 646 \\
\hline Sentimen Negatif & 1684 \\
\hline Total & 2330 \\
\hline
\end{tabular}

Setelah data diberi label, pada Tabel 3 dapat dilihat bahwa dari 4292 tweets hasil preprocessing, sejumlah 2330 tweet termasuk ke dalam sentimen positif dan negatif, sedangkan sisanya yaitu sebesar 1962 tweet bersentimen netral yang tidak digunakan dalam penelitian ini. Dari kedua sentimen yang digunakan, dapat dilihat bahwa tweets lebih banyak termasuk ke dalam kategori sentimen negatif. Berdasarkan tweets tersebut, kemudian dilakukan perhitungan frekuensi kata yang digunakan oleh pengguna twitter dimana hasilnya dapat dilihat pada Gambar 2 dan 4.

\subsection{Klasifikasi Sentimen dengan Naive Bayes Classification}

\section{Pembentukan Data Testing dan Training}

Pada penelitian ini, tahap selanjutnya adalah membagi data yang telah dibersihkan menjadi dua yaitu data training dan data testing dengan rasio pembagian 80:20. Berdasarkan rasio tersebut, diperoleh sebanyak 1864 tweet yang akan digunakan sebagai data training dan sebanyak 466 tweet sisanya digunakan sebagai data testing. Setelah pembagian data menjadi dua telah dilakukan, kemudian dilakukan evaluasi model. 


\section{Evaluasi Model Naive Bayes Classification}

Penghitungan tingkat akurasi, sensitivitas, dan spesifisitas merupakan salah satu cara yang dapat dilakukan untuk mengevaluasi model klasifikasi Naive Bayes Classification. Adapun hasil dari aplikasi model pada data testing menghasilkan tabel confusion matrix yang dapat dilihat pada tabel berikut.

\begin{tabular}{|c|c|c|}
\hline \multirow{2}{*}{$\begin{array}{c}\text { Kelas } \\
\text { Sebenarnya }\end{array}$} & \multicolumn{2}{|c|}{ Kelas prediksi } \\
\hline & Positif & Negatif \\
\hline Positif & 94 & 22 \\
\hline Negatif & 37 & 313 \\
\hline
\end{tabular}

Tabel 5 menunjukkan hasil evaluasi dari model Naive Bayes Classification yaitu diperoleh tingkat akurasi klasifikasi sebesar 87,34\%, sensitivitas sebesar 93,43\%, dan spesifisitas 71,76\%. Berdasarkan hasil ketiga jenis ukuran tersebut dan validitas keseluruhannya dapat dilihat bahwa penggunaan metode naive bayes sudah cukup baik dalam mengklasifikasikan sentimen negatif maupun positif.

\subsection{Visualisasi Hasil Klasifikasi}

1. Analisis Sentimen

Distribusi Persentase Cuitan Berdasarkan Sentimennya

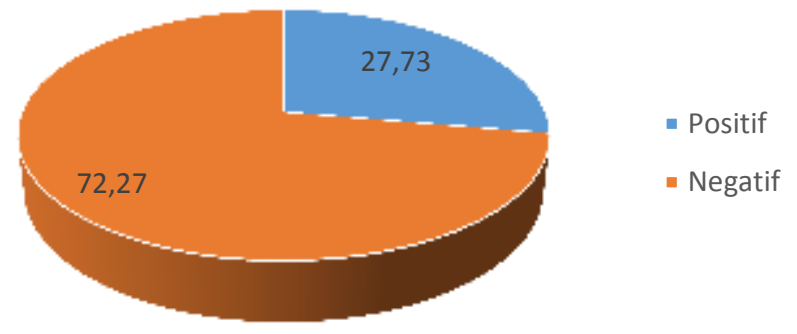

\section{Gambar 1. Distribusi Persentase Cuitan Berdasarkan Kelas Cuitan Positif Dan Negatif}

Berdasarkan Gambar 1. dapat dilihat bahwa masyarakat lebih banyak memberikan sentimen/komentar negatif terhadap beberapa kebijakan seperti PSBB, wajib masker, dan jam malam pada masa yang mendekati berakhirnya salah satu kebijakan terkait penanganan COVID-19 yaitu PSBB Masa Transisi Menuju Masyarakat Sehat, Aman, dan Produktif di DKI Jakarta. Hal tersebut dipertegas dengan melihat nilai persentase pada kedua sentimen, di mana sentimen negatif memiliki presentase lebih besar yaitu sebesar $72,27 \%$. Selisih antara sentimen positif dan negatif yang cenderung besar ini mengindikasi bahwa masyarakat yang menjadikan twitter sebagai sarana publik untuk mengemukakan pendapat, sebagian besar masih merasa kecewa terhadap kebijakan yang ada. Menurut hasil penelitian [18], kekecewaan masyarakat terhadap kebijakan penanganan COVID-19, PSBB, dapat disebabkan karena mobilitas masyarakat semakin terbatas yang berakibat pada semakin sulitnya kondisi ekonomi. Berkaca dari hal tersebut, seharusnya kekecewaan masyarakan dapat dijadikan masukan atau evaluasi terhadap kebijakan yang sedang diterapkan.

2. Barplot Sentimen Positif

Berdasarkan total 646 tweets bersentimen positif yang memuat 7058 kata, Gambar 2 menunjukkan lima kata dengan frekuensi paling tinggi yang digunakan pengguna twitter. 


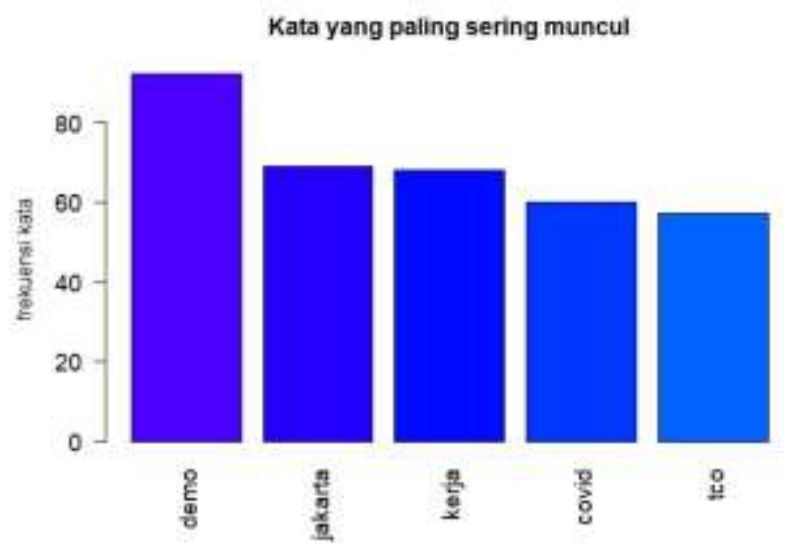

\section{Gambar 2. Distribusi Frekuensi Kata-Kata Yang Paling Sering Muncul Pada Kelompok Sentimen Positif}

Pada Gambar 2 dapat dilihat bahwa kata yang paling sering muncul dari kelas sentimen positif adalah kata "demo" sebanyak 92 kata. Kata tersebut adalah kata yang paling sering diulas oleh pengguna twitter dalam penyampaikan aspirasinya terkait dukungannya pada kebijakan penanganan COVID-19 oleh pemerintah di Indonesia.

3. Wordcloud Sentimen Positif

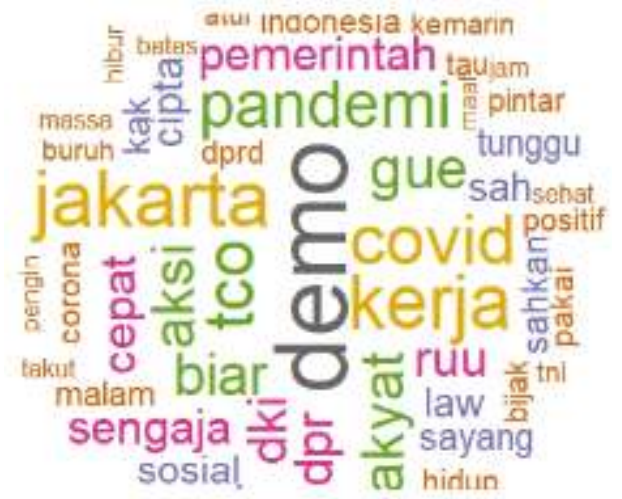

Gambar 3. Wordcloud Kata-Kata Kelompok Sentimen Positif

Kata-kata sentimen positif yang disajikan dalam bentuk wordcloud dapat dilihat pada Gambar 3. Dapat dilihat kata-kata yang menunjukkan bentuk pernyataan setuju pengguna twitter terhadap kebijakan penanganan COVID-19 oleh pemerintah di Indonesia yang meliputi PSBB, jam malam, dan wajib masker. Ukuran kata pada wordcloud menunjukkan seberapa banyak frekuensi kata yang muncul. Semakin besar ukuran kata, semakin tinggi pula frekuensi kata tersebut digunakan oleh pengguna twitter. Berdasarkan wordcloud sentimen postitif, kata yang paling sering muncul adalah kata "demo", kemudian diikuti dengan kata "jakarta", "covid" dan "kerja". Hal tersebut dikarenakan selama rentang waktu scrapping data, sedang marak demo dalam rangka menolak UU Cipta Kerja sehingga peristiwa ini sering disebutkan dalam cuitan masyarakat dalam menunjukkan dukungan atau persetujuannya atas kebijakan penanganan COVID-19 yang diterapkan. Di sisi lain, frekuensi kata "jakarta" yang tinggi dalam tweet masyarakat saat itu mengindikasikan bahwa Jakarta merupakan salah satu daerah yang disoroti terkait pelaksanaan kebijakan penanganan COVID-19. Hal tersebut menyebabkan kata ini sering digunakan, tidak terkecuali dalam penyampaian bentuk dukungan maupun hal-hal positif terkait kebijakan yang sedang diterapkan. Alasan tingginya frekuensi kata tersebut juga didukung oleh waktu pengumpulan data yang mendekati berakhirnya PSBB Masa Transisi Menuju Masyarakat Sehat, Aman, dan Produktif yang diterapkan di DKI Jakarta. Adapun kata-kata lain yang ada di dalam wordcloud namun berukuran kecil menunjukkan bahwa pengguna 
yang membicarakan hal tersebut tidak sebanyak kata "demo", "jakarta", dan "covid" dalam mendukung kebijakan penanganan COVID-19 oleh pemerintah.

4. Barplot Sentimen Negatif

Berdasarkan 1684 tweets bersentimen negatif yang memuat 18244 kata, Gambar 4 menunjukkan lima kata dengan frekuensi paling tinggi yang digunakan pengguna twitter.

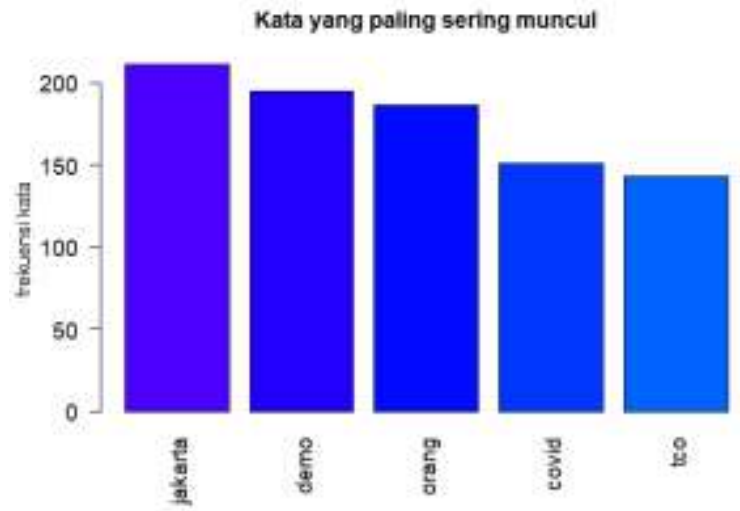

\section{Gambar 4. Distribusi Frekuensi Kata-Kata Yang Paling Sering Muncul Pada Kelompok Sentimen Negatif}

Berdasarkan Gambar 4 dapat dilihat bahwa kata "jakarta" paling banyak muncul pada kelas sentimen negatif dengan frekuensi sebanyak 211 kata. Hal tersebut menunjukkan bahwa kata "jakarta", merupakan kata yang paling banyak digunakan oleh pengguna twitter dalam tidak menyetui kebijakan pemerintah dalam penanganan COVID-19 di Indonesia.

5. Wordcloud Sentimen Negatif

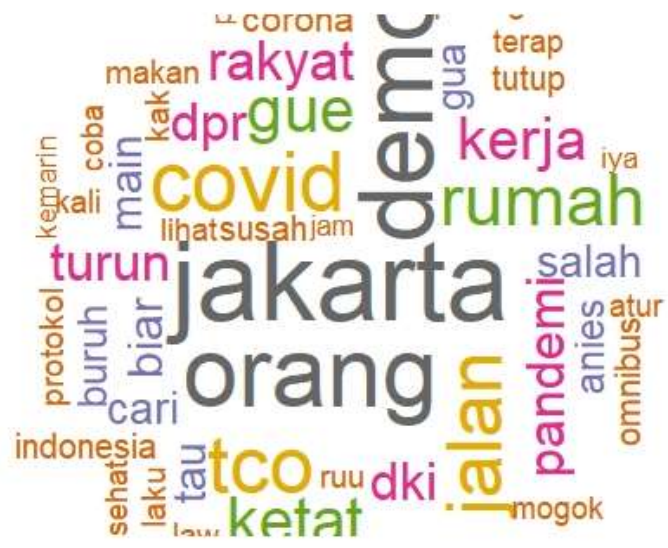

Gambar 5. Wordcloud Kata-Kata Kelompok Sentimen Negatif

Berdasarkan ukuran katanya pada wordcloud di Gambar 2, dapat dilihat bahwa "demo", "jakarta" merupakan kata yang paling sering digunakan pada sentimen negatif yang dicuitkan pada twitter, disusul kata "orang" disusul kata "covid", "tco" dan "jalan". Kata-kata pada sentimen negatif menunjukkan bentuk pernyataan tidak setuju pengguna twitter terhadap hal yang berkaitan dengan kebijakan penanganan COVID-19 yaitu PSBB, jam malam, dan wajib masker. Kata "demo" yang muncul sebagai kata dengan frekuensi tertinggi memiliki alasan yang sama dengan kemunculannya pada sentimen positif yaitu maraknya pelaksanaan demo dalam rangka penolakan terhadap disahkannya UU Cipta Kerja. Peristiwa atau kejadian ini dijadikan sebagai alasan kekecewaan masyarakat dalam cuitan yang bersentimen negatif karena dalam pelaksanaan demonstrasi dapat ditemukan oknum-oknum yang melanggar kebijakan PSBB, wajib masker, dan jam malam. Di sisi lain, seperti yang terjadi pada sentimen positif, pada tweet masyarakat yang terklasifikasi sebagai 
sentimen negatif, kata "jakarta" juga memiliki frekuensi penggunaan yang tinggi. Hal tersebut menunjukkan bahwa tweet kekecewaan masyarakat terhadap kebijakan penanganan COVID-19 yang sedang diterapkan khususnya PSBB, wajib masker, ataupun jam malam identik dengan pelaksanaannya di Jakarta. Fakta ini juga dapat dilihat dari kalimat tweet bersentimen negatif yang menggunakan kata "jakarta". Kata-kata lain yang digunakan dalam menyatakan sikap tidak setuju terhadap kebijakan penanganan COVID-19 namun tidak sebanyak kata "demo", "jakarta", dan "orang" dapat dilihat di sekitarnya dengan ukuran lebih kecil atau relatif sama.

\section{Kesimpulan}

Berdasarkan hasil pengujian yang telah dilakukan, dapat disimpulkan bahwa masyarakat lebih banyak memberikan sentimen negatif terhadap kebijakan penanganan COVID-19 khususnya PSBB, wajib masker, dan jam malam yaitu sebesar 72,72 persen. Pada sentimen positif, tiga kata dengan frekuensi kemunculan terbanyak yaitu demo, jakarta, dan kerja. Sedangkan pada sentimen negatif yaitu jakarta, demo, dan orang. Adapun kemunculan kata demo dan jakarta pada kedua sentimen menunjukkan bahwa tweet/cuitan masyakat mengenai kebijakan penanganan COVID-19 tidak dapat lepas dari peristiwa atau kejadian saat pengumpulan data dilakukan yaitu demontrasi UU Cipta Kerja dan hampir berakhirnya PSBB Masa Transisi Menuju Masyarakat Sehat, Aman, dan Produktif di DKI Jakarta. Selain itu, tingginya frekuensi kata "jakarta" pada sentimen negatif juga menunjukkan bahwa pelaksanaan kebijakan penanganan COVID-19 khususnya PSBB, wajib masker, dan jam malam di Jakarta belum dilaksanakan secara optimal. Berdasarkan hasil evaluasi, diperoleh tingkat akurasi klasifikasi sebesar 87,34\%, sensitivitas sebesar $93,43 \%$, dan spesifisitas $71,76 \%$ yang berarti metode ini sudah cukup baik dalam mengklasifikasikan sentimen negatif maupun positif. Hal tersebut menunjukkan bahwa respon publik terhadap suatu isu terkini dapat diketahui dari media sosial seperti twitter sebagai sumber informasi dan sumber data alternatif. Berdasarkan frekuensi kata yang tinggi, dapat dilihat hal yang dikomentari masyarakat melalui kalimat cuitan, salah satunya kekecewaan atas pelaksanaan kebijakan penanganan COVID-19 di Jakarta yang menunjukkan bahwa kebijakan yang ada belum dilaksanakan secara optimal. Hal tersebut kemudian dapat dijadikan sebagai bahan evaluasi bagi pemerintah daerah terkait untuk lebih mengoptimalkan kebijakan yang ada. Adapun untuk penelitian berikutnya dapat menggunakan sumber data dari internet atau media sosial lain dan menggunakan metode supervised learning yang berbeda untuk menganalisa berbagai hal terkini yang pada akhirnya memberikan suatu pengetahuan baru.

\section{Referensi}

[1] Yuliana, "Corona Virus Diseases (Covid -19); Sebuah Tinjauan Literatur," Wellness Heal. Mag., Vol. 2, No. February, pp. 124-137, 2020, doi: 10.2307/J.Ctvzxxb18.12.

[2] Gugus Tugas Percepatan Penanganan COVID-19. 2020, "Infografis COVID-19," Infografis COVID-19, 2020. Https://Covid19.Go.Id/ (Accessed Sep. 11, 2020).

[3] T. Nichols, Matinya Kepakaran. Jakarta: Gramedia Pustaka Utama, 2018.

[4] S. Suryono, E. Utami, and E. T. Luthfi, "Analisis Sentiment Pada Twitter Dengan Menggunakan Metode Naïve Bayes Classifier," Semin. Nas. Geotik 2018, pp. 9-15, 2018.

[5] M. Syarifuddin, "Analisis Sentimen Opini Publik Mengenai Covid-19 Pada Twitter Menggunakan Metode Naïve Bayes dan Knn," Inti Nusa Mandiri, Vol. 15, No. 1, pp. 23-28, 2020.

[6] E. I. Elmurngi and A. Gherbi, "Unfair Reviews Detection on Amazon Reviews Using Sentiment Analysis With Supervised Learning Techniques," J. Comput. Sci., Vol. 14, No. 5, pp. 714-726, 2018, doi: 10.3844/Jcssp.2018.714.726.

[7] B. Liu and B. Liu, the Problem of Sentiment Analysis. Cambridge University Press, 2015.

[8] I. Rish, "An Empirical Study of the Naïve Bayes Classifier an Empirical Study of The Naive Bayes Classifier," Cc.Gatech.Edu, No. January 2001, pp. 41-46, 2014, [Online]. Available: Https://Www.Cc.Gatech.Edu/ Isbell/Reading/Papers/Rish.Pdf.

[9] S. Hikmawan, A. Pardamean, and S. N. Khasanah, "Sentimen Analisis Publik Terhadap Joko Widodo Terhadap Wabah Covid-19 Menggunakan Metode Machine Learning," Vol. 20, No. 2, pp. 167-176, 2020. 
[10] W. Bimananda, I. Riski, K. Dwi, R. Nooraeni, and T. Siahaan, "Analisis Text Mining Dari Cuitan Twitter Mengenai Infrastruktur di Indonesia Dengan Metode Klasifikasi Naïve Bayes," Eig. Math. J., Vol. 2, No. 2, 2019.

[11] S. Pramana, B. Yuniarto, S. Mariyah, I. Santoso, and R. Nooraeni, Data Mining Dengan $R$ Konsep Serta Implementasi. Bogor: Penerbit IN Media, 2015.

[12] A. Roihan, P. A. Sunarya, and A. S. Rafika, "Pemanfaatan Machine Learning Dalam Berbagai Bidang: Review Paper," IJCIT (Indonesian J. Comput. Inf. Technol., Vol. 5, No. 1, pp. 75-82, 2020, doi: 10.31294/Ijcit.V5i1.7951.

[13] I. Muhammad and Z. Yan, "Supervised Machine Learning Approaches: A Survey," ICTACT J. Soft Comput., Vol. 05, No. 03, pp. 946-952, 2015, doi: 10.21917/Ijsc.2015.0133.

[14] A. Wibowo, M. D. Hidayat, And R. Dzakiyyah, "Analisis Sentimen Masyarakat Terhadap Calon Presiden Indonesia 2019 Berdasarkan Opini Dari Twitter Menggunakan Metode Naive Bayes Classifier," 2019.

[15] Bustami, "Penerapan Algoritma Naive Bayes untuk Mengklasifikasi Data Nasabah Asuransi," Vol. 8, No. 1, pp. 884-898, 2014.

[16] Y. Watequlis Syaifudin and D. Puspitasari, "Twitter Data Mining for Sentiment Analysis on Peoples Feedback Against Government Public Policy," Matter Int. J. Sci. Technol., Vol. 3, No. 1, pp. 110-122, 2017, doi: 10.20319/Mijst.2017.31.110122.

[17] A. R. Susanti, "Analisis Klasifikasi Sentimen Twitter Terhadap Kinerja Layanan Provider Telekomunikasi Menggunakan Varian Naive Bayes," Institut Pertanian Bogor, 2016.

[18] R. Nasruddin and I. Haq, "Pembatasan Sosial Berskala Besar (PSBB) dan Masyarakat Berpenghasilan Rendah," SALAM J. Sos. Dan Budaya Syar-I, Vol. 7, No. 7, 2020, doi: 10.15408/Sjsbs.V7i7.15569. 